\title{
States of co-existence and border projects in port cities: Genoa and Rotterdam compared
}

\author{
Beatrice Moretti PhD \\ Architect, Department of Architecture and \\ Design - dAD, Polytechnic School of Genoa, Genoa, Italy \\ (corresponding author: beatrice_moretti@yahoo.it, \\ beatrice.moretti@edu.unige.it) (Orcid:0000-0003-0214-991X) \\ Susanne Komossa Dr. ir. \\ Associate Professor of Architecture, Chair of Architectural \\ Composition/Public Building, Faculty of Architecture and the Built \\ Environment, Delft University of Technology, Delft, the Netherlands \\ (Orcid:0000-0002-9203-7526)
}

\author{
Nicola Marzot Dr. Arch. \\ Assistant Professor of Architecture, Chair of Architectural \\ Composition/Public Building, Faculty of Architecture and the \\ Built Environment, Delft University of Technology, Delft, the Netherlands \\ (Orcid:0000-0002-2096-1859) \\ Carmela Andriani Dr. Arch. \\ Full Professor in Architecture and Urban Planning, Department of \\ Architecture and Design - dAD, Polytechnic School of Genoa, Genoa, Italy \\ (Orcid:0000-0002-0387-5027)
}

In port cities there is a tendency to dislocate production activities in favour of logistic-productive dynamics. In addition, the transition from an industrial area model to a 'logistics hinterland' formula shifts attention to a territorial scale, focusing on spaces at the border between the port and city areas. Today, port-city borders are commonly perceived as barriers but they could be dynamic development thresholds. Existing port cities exhibit different states of coexistence at their port-city borders: sometimes they are forced situations originating from poor management, but they can also provide opportunities for mutual interaction and synergy. This paper compares portcity borders in Genoa and Rotterdam using interviews, relevant literature and mapping. Conclusions are drawn concerning the possibilities and potential for future port-city borders.

\section{Framework}

\subsection{Globalisation and port dynamics}

At the beginning of the new century, globalisation affected economy and trade, giving rise to new models of landscape related to a complex set of movements and logistics. As Charles Waldheim (Waldheim, 2016; Waldheim and Berger, 2008) acknowledges in his research, these forms of landscape (called 'logistics' or 'operative' landscapes) became a testing ground for new kinds of settlements and potential architecture.

Global phenomena have led to a total restructuring of the urban, economic and productive balance of urban spaces all over the world. The infrastructural system has become one of the most stressed organisms, one that has faced radical change in terms of the functioning, role and relationship with the city.

Port infrastructures, for example, have been reformed in terms of services and spaces, becoming nodes of increasingly articulated networks, points of entry for ocean maritime traffic with solid connections to the overall logistics system. This profoundly changes the port-city model, giving rise to new conditions between the two entities that can only be understood on a global scale.

The most recent studies on the theme of world cities come from the work of the Globalization and World Cities Group
(GaWC) and mainly focus on the effects that the advent of globalisation has brought to cities and territories. Despite the important contributions of these explorations, the studies of geographers, Verhetsel and Sel, find a gap in the work of the GaWC when it comes to the theme of the global city in the maritime and port sector, the so-called 'world maritime city'.

However, in no sector was the process of globalisation and its effects as profound as in the urban-port areas. Therefore, the results of Verhetsel and Sel's research make it possible to state that many of the poles listed as global cities actually have a decisive maritime and port focus.

In addition to this, at the end of the second millennium, the technological revolution based on information made relevant changes to the structure of society: the economy became global, and world society shaped its morphology accordingly, creating a system with variable geometry based on the network scheme.

In his trilogy about the origins of the network society, Manuel Castells (1996a) explores these phenomena in depth, arguing that the birth and progressive diffusion of the new social structure have important repercussions on the concept of 'space'. In particular, he affirms that the global and informational economy of the new millennium creates the so-called 'space of flows', an unprecedented spatial configuration determined by the new logic and structured by the networked system. 
The space of flows is the dominant spatial manifestation of the power and function of the new global society. From the dialectical opposition between 'spaces' and 'flows', not only do important factors of change emerge for the architectural and urban planning disciplines, but interesting points of observation for cities, in terms of production, logistics and trade, are also consolidated.

\subsection{Globalisation and the port-city relationship}

Globalisation changed the urban spatiality and the productive space of the logics of commerce, in particular in relation to large infrastructural hubs such as ports. As already described, the advent of the digital era allowed the entry of automation and delocalisation into production processes and, since each phase of the process could be split and completed in different places and times, there was a real dissociation between spatial proximity and the completion of trade activities.

In the realm of port cities, global phenomena are triggering a tendency to dislocate production activities in favour of logistic-productive dynamics confirming the progressive outplacement of the port as a contemporary and growing phenomenon, also motivated by environmental issues and by the increasing pressure of the real estate market towards central urban areas.

This is clearly a growing phenomenon that removes and, at the same time, dematerialises the main components of production, moving heavy port functions (such as oil and chemical products but also commercial terminals) to areas farthest from the city, to hinterland areas (i.e. dry ports) or towards the mouths of rivers, in the case of fluvial ports. Systems of logistics and mobility, then, are rapidly replacing those spaces to support the needs of the port as a gateway. This process thereby justifies the transition from a 'port-city-industrial areas' model to a new 'port-city-logistics hinterland' formula, shifting the attention on a territorial scale. Accordingly, the result of this phenomenon is bringing the destiny of spaces and artefacts located on the border between port and city to the fore, due to the changes in production and land use.

If, on one hand, the transfer of port areas away from the city minimises the frictions on the port-city border, on the other, it triggers significant revolutions and introduces unprecedented scenarios for the use of these intermediate areas between port and city.

In fact, once these border areas have been a focal point, they then become mainly places of contention between the authorities that converge on the institutional border. Depending on the contexts and ongoing processes, in fact, they are freed, dismantled, altered and, more than others, must compensate for the consequences of these global transformations.

During this metamorphosis, the port-city border dimension generates different states of coexistence between the two territories. These states of coexistence affect spatiality, relations and future development. Sometimes they are forced situations that create difficulties in the management of spaces and equipment, but they can also be sources of new opportunities for mutual interactions and symbiotic synergies.

\section{Urban-port threshold}

\subsection{Borders are everywhere}

In the era of globalisation and transnational flows, the multiplicity of borders in urban planning and landscape imaginaries is a lens through which to illustrate changing configurations of the social and political contexts. According to geographical thinking, 'In the late 1980s the transition from the concept of border to that of bordering [...] allowed borders to be viewed as dynamic social processes of spatial differentiation' (Brambilla et al., 2015). From this point of view, it is possible to assert the potentiality of borders as fields of research and to grasp their dynamic and symbolic character in space and time.

Globalisation has severely impacted territoriality from a theoretical point of view, but mostly it has conditioned its transformation and management potentialities. It has 'de-solidified' the contemporary world, asserting its fluid and liquid complexity (Bauman, 2000), but above all it has introduced the 'borderless' world model.

However, paradoxically and only in this context does the topic of borders return: '[The] border, that seemed over-passed during globalisation, now comes back strongly boosted in a universal dimension. Globalization is the shifting of the border until its conceivable limits' (Ferrara, 2011: p. 190). This means that at the turn of the new century, many various typologies of borders, such as static or naturalised lines, emerge to mark limits usually for reasons of surveillance, regulation and fear.

Therefore, as Paasi (1996) reported, 'Borders are everywhere': this multiplication of borders turns them into interpretative lenses of the contemporary condition of territories and communities and also into strategic objects that are valuable for defining new operative meanings and tools in planning fields.

The concept of a border is, at the same time, interesting and controversial. The proliferation of terms coined to represent the diversity of borders, moreover, seems to confirm both the richness and the disorder of the issue. Border, boundary, limit, margin, but also barrier, frontier or interface, more or less each of these terms refers to the same basic concept with a diverse 
gradient of openness and closure: an element that is located 'between' other things, that divides, that communicates the end of a situation and the beginning of another, that marks a decisive structural variation. Going further, it is possible to affirm that a border is something that by separating connects (or vice versa, which separates by connecting) and, moreover, that produces a field with its own genetic characteristics (Rumford, 2006).

These lines of thought often result in varied and complex disciplinary fields. The terms listed above are not synonymous, but allow variations that often depend on the overall scenario. Still, two guiding ideas should be highlighted. First, a border is an element with a variable thickness and size whose form is difficult to represent in a finite way. Second, a border is an intermediate space made of streams, bonds and trade, a 'unifying suture' more than an 'insulating barrier' (Lynch, 1964). In this research study, a border is conceived as a liminal space where two authorities converge and diverge. It is a field of research that represents the bond between different forms of power and urban patterns, defining notions such as citizenship and territorial identity.

\subsection{Borders and borderscapes}

Among the most interesting studies on the combination between borders and landscapes, the research by the Dutch planners Topotronic led by Arjan Harbers is worth mentioning. Even in their study, the political-institutional component of borders emerges as an influencing factor: 'Political ideologies have affected architecture since earliest times. Government buildings and urban ensembles reflect not only the zeitgeist but also the political climate at the time of building. [...] An attempt to make sense of this patchwork [...] with different political systems, traditions and alliances requires case studies, new classifications and recommendations on a continental scale. The best places to carry out such research are border areas, the fault lines between political entities' (Harbers, 2005: p. 143).

Subsequently, Harbers extends his vision and affirms that, in the presence of infrastructural complexes, borders become powerful spatial devices. 'Magnets' like these (i.e. fast rail links, airports and motorways) shape and solidify the urban field into one of a number of scapes. We shall describe the distortions borders bring to the built environment or nature as 'border solidifications' or borderscapes. Borderscapes can find expression in various ways' (Harbers, 2005).

The formulation of the term 'borderscape' is part of a widespread practice of using the suffix '-scape' to give to certain spatial components a conceptual complexity and, at the same time, a certain degree of ambiguity. As with the word 'landscape', this suffix not only confers aesthetic and symbolic values but, above all, links its original meaning to the term 'shape' referring to the action of 'giving shape' to spaces.

Following this reasoning, the potentialities of borders 'as spaces' become evident both in physical and symbolic terms. As Piero Zanini (2000) outlined, the study of borders can be very challenging due to their multiplicity and indefiniteness. Therefore, what is crucial is not exploring the 'border space' but above all the border 'as a space'.

Because of their intermediate and neuralgic position, borderscapes are also places of creativity and hybridisation: in their field more than in others, in fact, we can detect heterogeneity, liveliness and authenticity. On this topic, Richard Sennett said, 'It is at the borderline where the work of natural selection is the most intense', and also adds that, in this perspective, 'Time is productive of evolutionary change in this edge condition'. For these reasons, we have to recognise the strategic role of time in relation to spatial transformation, in particular as it relates to dynamic infrastructures: the 'time' factor, in fact, commutes the border into an open condition (Sennett, 2016).

\subsection{From border to threshold}

In some particular cases - that is, the border between a city and its own port, interesting characteristics of alliance and synergy along the border are detected.

The port condition always shows a certain tendency to change. Because of the incessant technological developments and the global maritime and commercial dynamics, the structure of the port city is often subject to profound cycles of upgrading. The most complex and evident combination of patterns and fluxes condenses along the administrative boundary: although it is often perceived as space of conflict, the liminal landscape located between a city and its port is a responsive interface characterised by strategic potentialities and, first, subjected/willing to change.

The border between port and city is a political figure, a new interface whose origin is parallel to the emergence of a new territory that has its own grammar and language. This border is a consequence of the first port consortiums that were internationally set up as independent entities beginning in the 1950s (Daamen and Vries, 2012).

However, the border between city and port is not only a polyline marked on maps but, instead, it has the potentiality to be considered a threshold (Schoonderbeek, 2013). A threshold is a system, or a concept, or a series of mechanisms that, collectively and individually, closely or tenuously, link port and city. A perceptible interface with a variable thickness and dimension 
that generates a new and recurrent urban-port condition in the close environment.

The transition from the idea of a border to the one of a threshold, indeed, is not casual but is a precise choice. In this way, in fact, the border expands its meaning, distinguishing itself from the idea of a boundary, limit or margin and acquiring a sense of motion and metamorphosis.

As Sergio Crotti (2000) pointed out, the threshold is an architectural figure where, while flows and forces converge and diverge, the identity and character of communities and places condense. In its territory, which separates and links port and city, not only the multiplicity of economic, commercial, logistic, but also cultural interactions are condensed, and the intensity of the relationships that describe the contemporary urban-port state is clearly represented.

\section{Comparison along the urban-port threshold}

\subsection{Rotterdam cf. Genoa}

This study arises as a further investigation within broader and ongoing research regarding the conditions and the potentialities of the border landscape placed along the threshold between city and port in several case studies of the European context.

Methodologically, the investigation selects two port cities (Rotterdam and Genoa) in which a comparison and confrontation (cf.) develop between two border areas selected as examples: the $\mathrm{M} 4 \mathrm{H}$ for Rotterdam and the Waterfront di Levante for Genoa (Figures 1 and 2).

The two areas have been chosen according to some specific requirements: border localisation, recognition of an

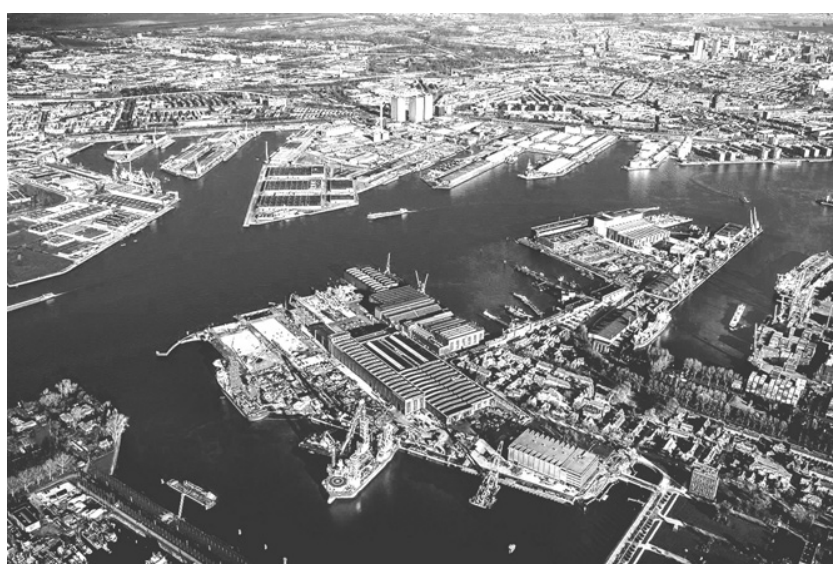

Figure 1. CityPorts Stadshavens districts and the $\mathrm{M} 4 \mathrm{H}$ area (above), general panorama (source: M4H official web site, 2018)

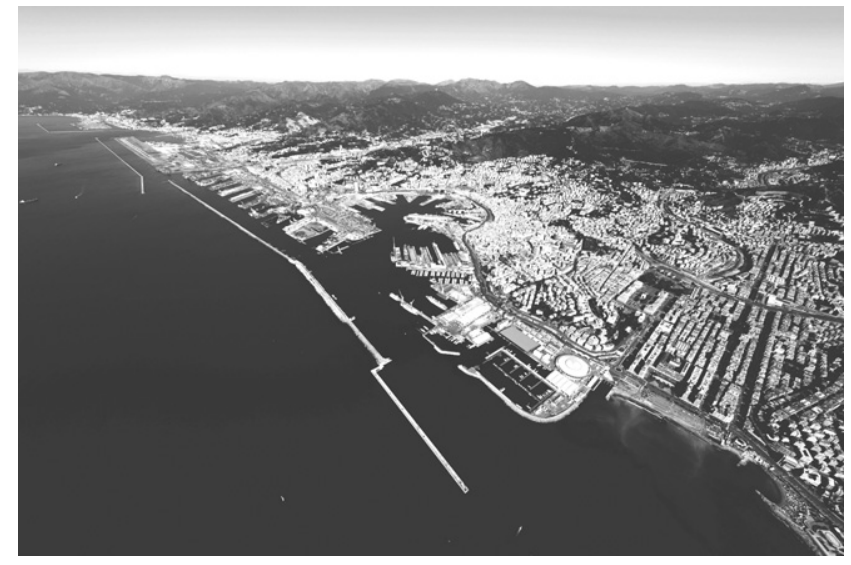

Figure 2. Waterfront di Levante and the Lotto 1 (on the right), general panorama (source: Autorità di Sistema Portuale del Mar Ligure Occidentale. Copyright: Roberto Merlo, 2013)

administrative limit that separates two territories, ongoing projects of regeneration developed by the local authorities and relevant governance models.

In both areas, the exploration of different (and often opposite) states of coexistence is the main goal, along with the intent to verify what has been advocated so far in greater depth. Moreover, through this comparison we aim to develop a method capable of introducing a new and more in-depth phase of research. In this further step, indeed, the role of planning and project and, at the same time, of strategies and actions emerge as a predominant theme.

\subsection{Rotterdam: the M4H}

\subsubsection{Planning and project/s}

Within the CityPorts Stadshavens Project (started in 2007), Rotterdam is transforming areas located along and across the urban-port boundary. The CityPorts Stadshavens Project is the largest inner-city development in Europe (after London Gateway) and covers 1600 ha of land and harbour basins. Almost the entire area is surrounded by dykes, heavy rail infrastructure and social housing neighbourhoods. In the Structure Vision for CityPorts that the municipality of Rotterdam developed in 2011 as a formal long-term plan, the area is divided into four different districts, each with its own existing profile and development trajectory. The southern WaalEemhaven area will be kept under the scrutiny of the port's management, the historical Rotterdam Dry Dock (RDM) (RDM Campus official site, 2018) area that has already been renewed into a campus with a cluster of innovative business and educational institutes and, finally, the Maas-Rijnhaven and Merwe-Vierhavens (Figure 3). 


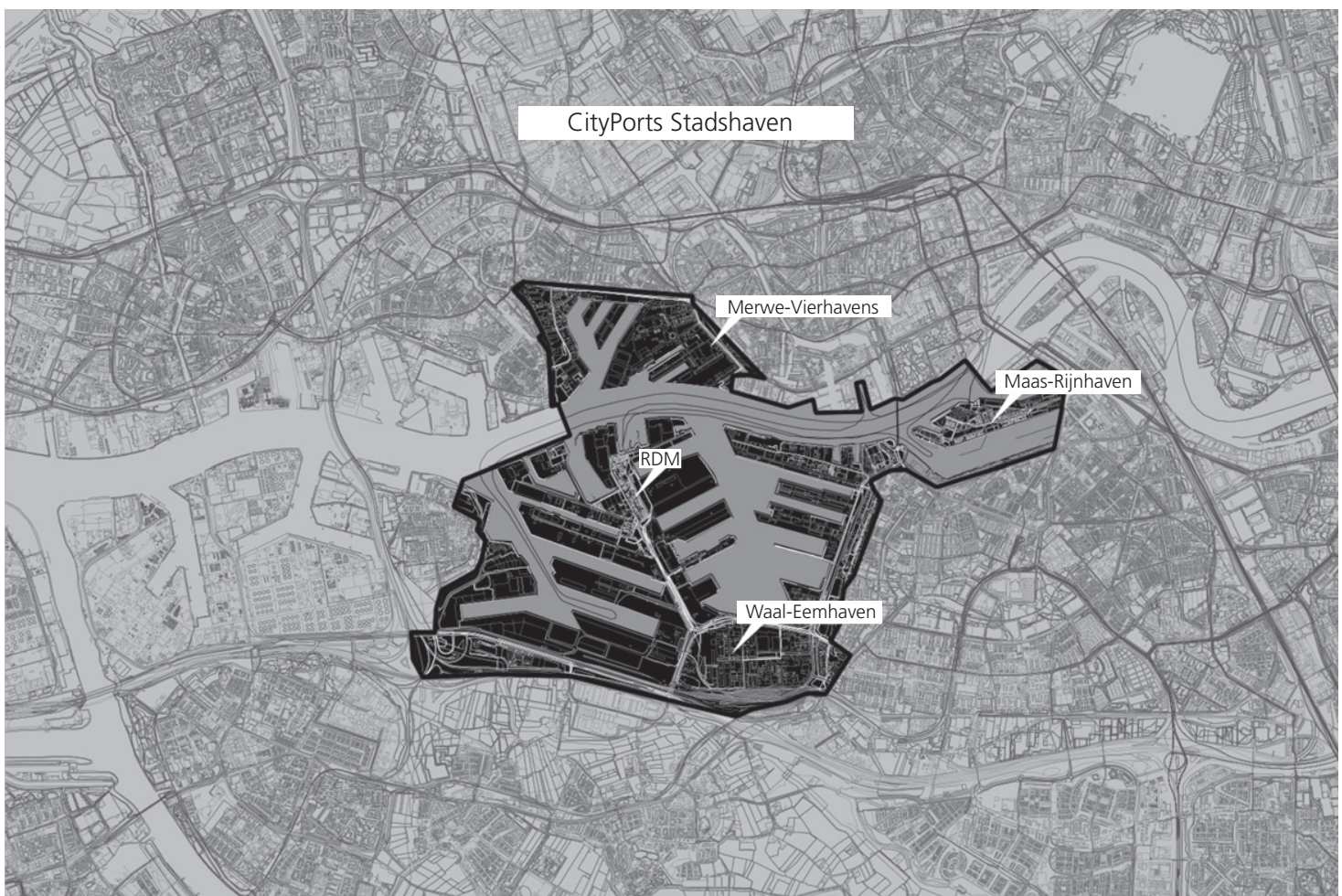

Figure 3. Port city of Rotterdam, map with individuation of the CityPorts Stadshavens districts: Waal-Eemhaven, RDM, Maas-Rijnhaven, Merwe-Vierhavens - M4H

The latter area, Merwe-Vierhavens (hereafter M4H) involves the transition of the former Merwe-Vierhavens port into an attractive urban area with low-density residential and business districts for new economic clusters, with a focus on sustainability (M4H official web site, 2018).

After almost a century of business, the fruit trade previously operative has been significantly thinned by competition from abroad, so what remains has been moved to the Waalhaven-Zuid, where a modern food distribution park is to be created.

With a joint strategy, the port authority and the municipality of Rotterdam have set out a complex programme of actions for the Merwe-Vierhaven quarter, aiming to transform it into an urban platform where the port and city meet.

For this purpose, unused areas and buildings have been made available for entrepreneurs with innovative and technological companies, mostly involved in the 'clean-tech, medical and food sector'. Both the municipality and the port authority made physical investments in the outdoor space and in the redevelopment of historic buildings; in the long run, they aim to trigger a dynamic process for the realisation of a circular manufacturing industry where living and working will be seamlessly connected (Figure 4).

\subsubsection{Governance}

$\mathrm{M} 4 \mathrm{H}$ is actually a site of experimentation in the field of economy, scientific research and, primarily, urban regeneration. Of course, the decision that in 2004 formalised the Port of Rotterdam Ltd as a public limited company with two main stakeholders, the municipality $(70 \%)$ and the Dutch State $(30 \%)$, is a key element in this process. Parallel to the institution of the new port guide, in fact, the Rotterdam CityPorts Development Corporation was constituted as an independent organisation managed in equal parts by the Port of Rotterdam Ltd $(50 \%)$ and the Rotterdam Municipal Government (50\%). Basically, the created corporation is in charge of all the CityPorts Stadshavens Project's strategic planning actions.

Some of the commercial port is still active in the area, but a big part of the basins and docks are in lively evolution, and new kind of projects and experimentations are on the horizon. Even if a broad vision and formal plan do exist, the two authorities are first trying to test a new set of tools, partly 


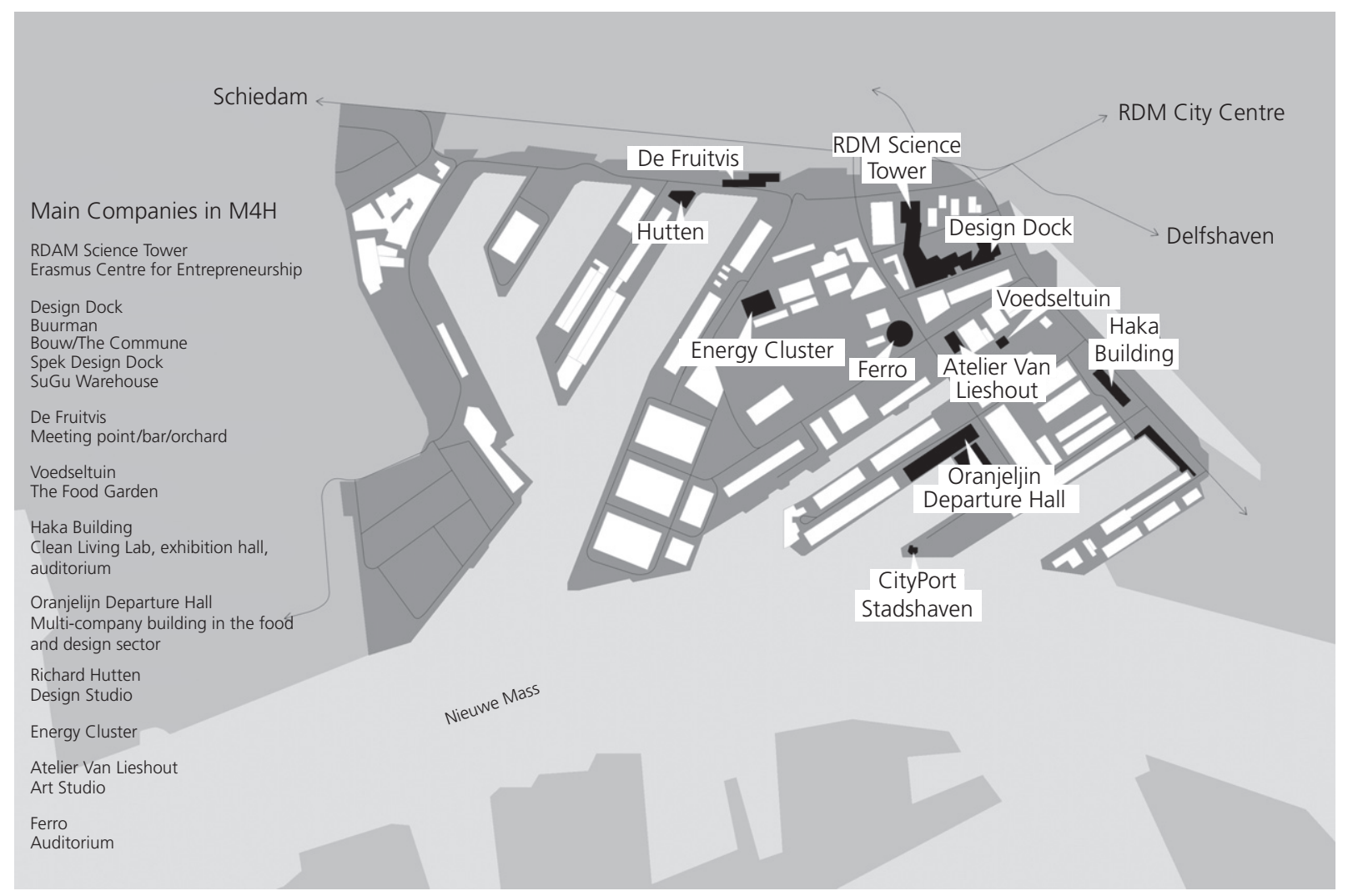

Figure 4. $\mathrm{M} 4 \mathrm{H}$ general plan with the main companies programmed by the ongoing project. In the present, $\mathrm{M} 4 \mathrm{H}$ is occupied by several companies focused mostly on scientific experimentations and on design and architecture. Some examples are the Rotterdam Science Tower located in one of the Europoint towers at Marconiplein, Buurman (a workplace of recycled wood and unused materials), Bouw/The Commune (a co-working studio involved in design, marketing, social training and didactic activities), Spek Design Dock (a collection building for creative entrepreneurs, makers and designers) and SuGu Warehouse (a booster of high-tech design and manufacturing) (source: BU, 2019)

unexplored. These instruments are mainly based on the realisation of a strong process that could be the foundation of a new spatial and social metamorphosis and crossover between city and port.

\subsubsection{A provisional state of coexistence}

Exploring the $\mathrm{M} 4 \mathrm{H}$ today, the ongoing mutation is perceivable. Although the overall image is rough, empty and bumpy, small businesses, hybrid solutions without a strict and sharp definition, interventions of temporary occupation and interim activities are slowly (but steadily) occupying the vacant places and warehouses (Figure 5).

As already mentioned, in Rotterdam the operative port is moving west, allowing for the possibility of operating in former port areas that are gradually being released from port activities. Nevertheless, port and city collaborate in the transformations, creating experimental border projects mostly based on contamination, innovation and sharing.

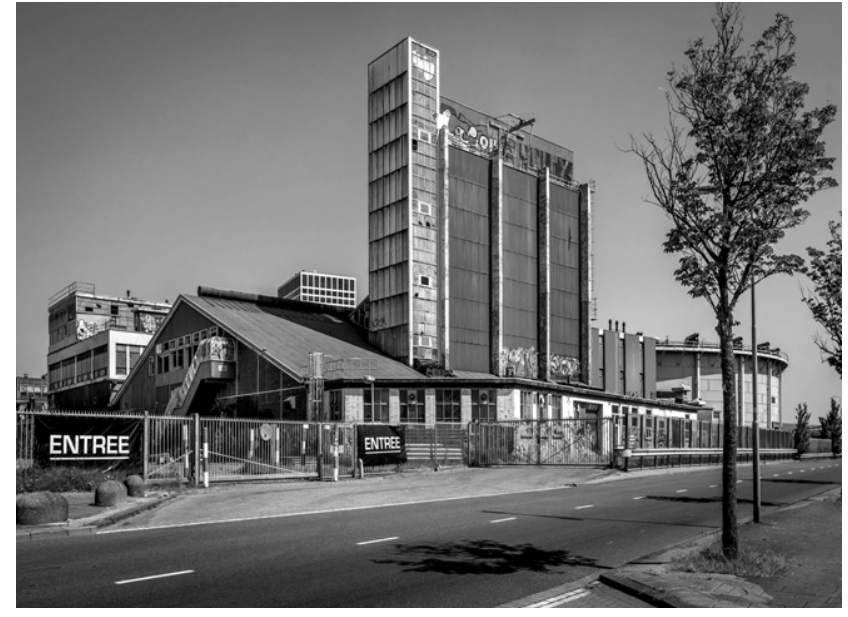

Figure 5. M4H area, detail of Ferro Auditorium (source: Port of Rotterdam, 2019) 
Therefore, we would say that in this particular case the coexistence is a very provisional and temporary situation due to the dynamism through which the area is disposed of, sold and then refurbished.

However, it seems very appropriate to recall Peter Hall's (2016) guideline according to which border areas between cities and ports should today be planned in a 'incomplete' or 'uncertain' way, considering the capacity of change of these territories.

Moreover, the issue of time is becoming particularly important and relevant in this reasoning and is converting into a design paradigm. The temporality of the coexistence is motivated by the active and mutable process through which activities occupy the abandoned warehouses and former terminal, providing new investments and energies.

However, a general plan for $\mathrm{M} 4 \mathrm{H}$ does exist, and it is going to be realised by the municipality in the next decade. Therefore, it is obvious to wonder in what way the existing companies will be managed, and if their presence will be considered the first phase of a wider development vision.

This inevitably brings to the fore the relationship between the bottom-up approach and the more definitive and long-term transformation plans. An innovative hypothesis on this topic may be to consider them not as antithetical and irreconcilable tools, but valid instruments belonging to different and often consequential moments of the general transformation process. In fact, the bottom-up approach is particularly effective in the beginning, although, after some time, temporary activities and pioneers can become part of a long-term vision for the development of the area; for this purpose, the municipality can help by facilitating space, legislation and connections with the larger industry.

Of course, this kind of planning process is a result of the port-city governance model. The administrative logic introduced in 2004, in fact, modifies the role of the port by encouraging its involvement in activities not directly or exclusively related to the sectoral authority profile and not necessarily internal to its territory. This is the so-called 'beyond the landlord role' theorised by Van der Lugt et al. (2013) through which the statute of 'government corporation' attributes to the port a much more direct position in the market.

\subsection{Genoa: waterfront di Levante}

\subsubsection{Planning and project/s}

Following the solution developed by the Renzo Piano Building Workshop (first drafted in 2013 and then officially presented in 2017), the port city of Genoa is proposing a radical transformation of its eastern waterfront. Actually, the Waterfront di Levante is a vision for a long coastline strip of $148000 \mathrm{~m}^{2}$ whose development aims to complete the overall profile of the seaside, giving continuity to the portion already reconverted in the past decades and located in the centre of the gulf (The Porto Antico and Darsena districts) (Figure 6).

The proposed Waterfront is located between the territories of the city (mostly residential neighbourhoods) and the port (active shipyards, refitting and repair companies, nautical and sport clubs); moreover, between the two areas there is a difference in height of about $20 \mathrm{~m}$, which makes the issue of accessibility and connection particularly controversial.

In general, the Waterfront di Levante project proposes to create a new urban waterfront together boosting up the port through a set of different actions: a full spatial rationalisation of the shipbuilding industry districts, the movement of the nautical clubs to the marina within the fair district and the reconstruction of the pilots' tower to replace the one that was destroyed by an accident in 2013. However, the key element in the project is the realisation of a water canal along the entire profile of the new coastline. This new waterway, partially navigable, has a double purpose: on one hand, it will detach the operative port giving it more space and freedom, on the other, it will unify the Porto Antico and Darsena areas with the eastern waterfront creating a new public promenade along the sea (Figure 7).

\subsubsection{Governance}

Even if, in the beginning, the Waterfront di Levante was a literal gift from the Renzo Piano Building Workshop to the city and to the local institutions (such as the Liguria Region, the municipality of Genoa and the Genoa Port Authority), today it is mainly an urban initiative.

In fact, the design scheme elaborated by the Genoese architect was first modified and then included in the Urban Master Plan (2015); currently, it is considered one of the key projects of the new City Council.

To pursue this goal, in 2016, the municipality announced a Competition of Ideas to collect proposals about a part of the Waterfront di Levante, the so-called 'Lotto 1'. This district, whose property belongs to the municipality, is located at the eastern end of the Waterfront and principally concerns the marina (with different pavilions from the 1960s), the shipyards and the yachting and sport centres. Ten projects were selected as finalists, but nobody won, denoting the difficulties of managing border areas. 


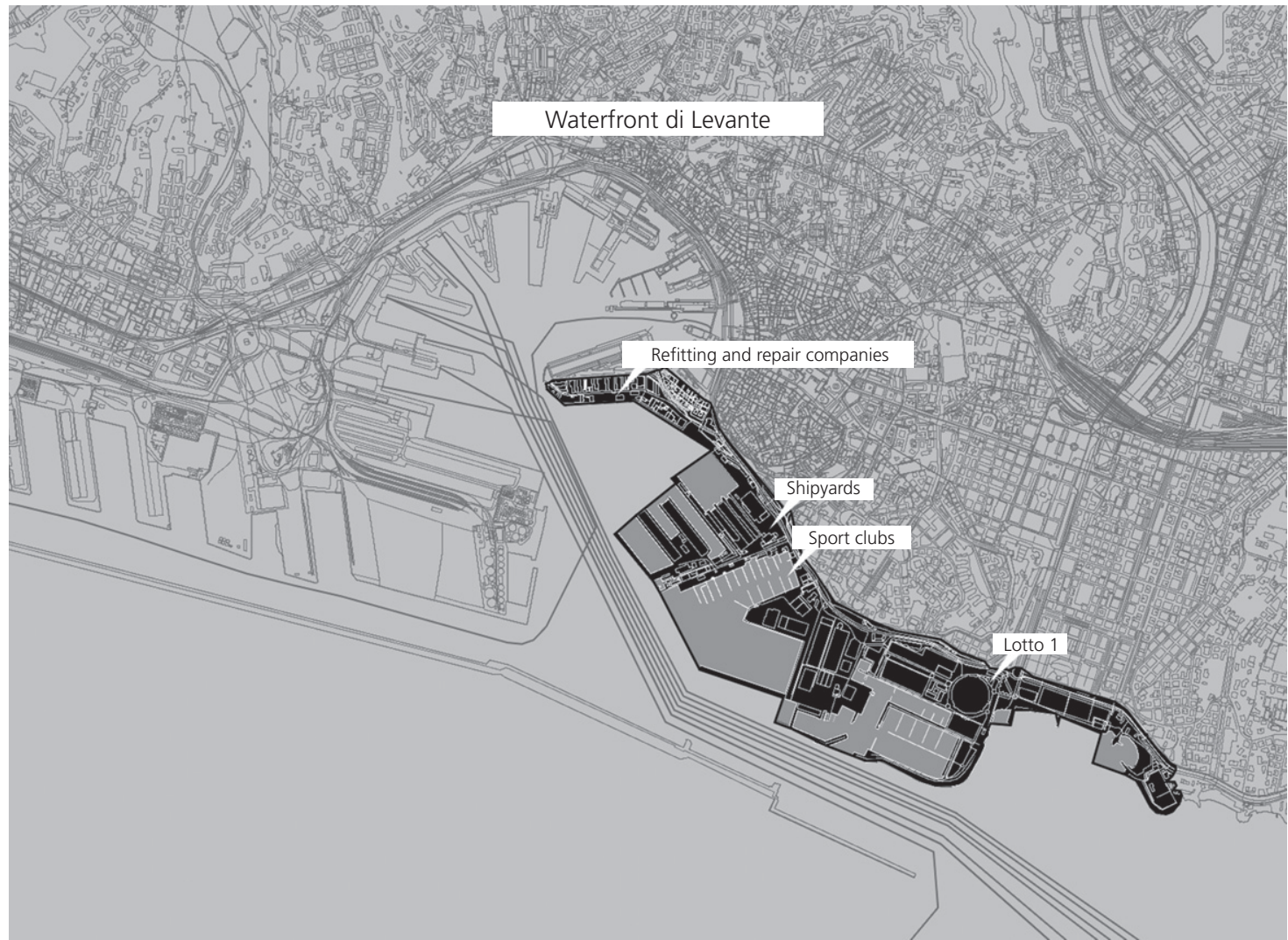

Figure 6. Port city of Genoa, map with individuation of the Waterfront di Levante area and, in particular the Lotto 1 (on the right) (source: Spim Genova, 2018)

On the other side, the Port System Authority is working on the Port Master Plan, also including the Waterfront di Levante proposal in the planning previsions. On this point, it is worth mentioning that the radical transformations introduced by the Ports Reform in 2016 already caused many issues and slowdowns.

The new configuration of the Italian port system, introduced by the Legislative Decree 4 August 2016 number 169, in fact, revolutionises the governance system by combining the actual 24 seaports into 15 territorial clusters (MIT, 2016). As an update of the national law number 84/1994, the first objective of the reform is the optimisation of port activities build through a systematic approach where differently sized ports unite in territorial clusters to enhance the importance of the territorial scale postulating the 'port-city-territory' model, a unique entity also in terms of governance.

In this perspective, the Port of Genoa is now a unique entity with the Port of Savona - Vado, located $40 \mathrm{~km}$ further west and a new organism, the Autorità di Sistema Portuale del Mar
Ligure Occidentale (Port System Authority), is now in charge of the two ports and has to develop an overall plan in the next future.

Nevertheless, nowadays the municipality is searching for a way to unlock the stationary situation, proposing a different approach in terms of urban and investment plans. In 2018, in fact, the Lotto 1 will be the subject of a call for tenders addressed to the sale of the areas: the proposals should contain an urban solution as well as a strong financing plan (Figure 8).

\subsubsection{A permanent state of coexistence}

Due to the location of the port within the city and the impossibility of moving operative activities elsewhere, the port and city in Genoa are literally squeezed between the mountains and the sea and in constant need of new solutions able to balance different flows and forces (Genoa Municipality official websites, 2018).

Thus, as in other areas of the common border, we would say that in the Waterfront di Levante project, the coexistence is a 


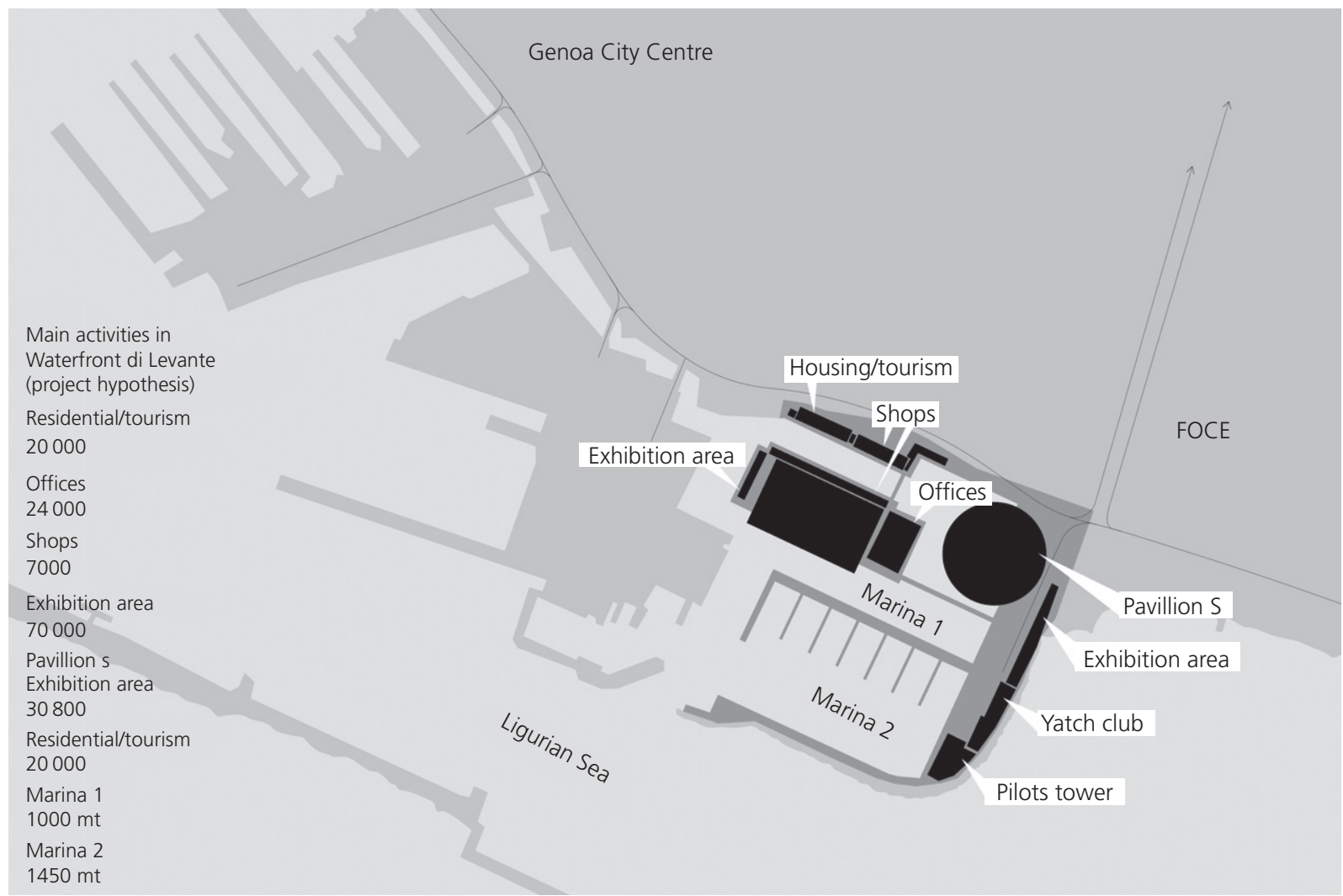

Figure 7. Waterfront di Levante general plan with the main activities programmed by the ongoing proposal. The Lotto 1, the first part of the Waterfront for which a more in-depth vision has been developed, it is composed of heterogeneous activities, partly related to the port activity and partly instead connected with the urban side. Some functions will occupy abandoned buildings, others, instead, will be located in new architectures (source: Genova Meravigliosa, 2018)

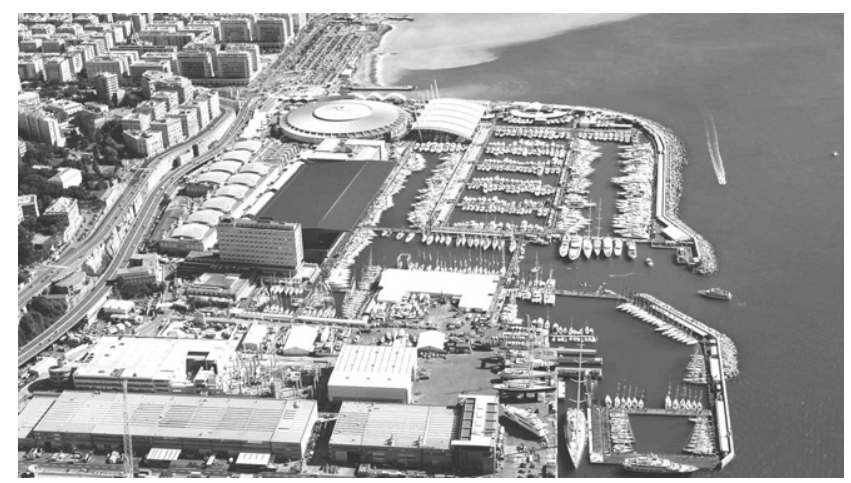

Figure 8. Waterfront di Levante, Lotto 1, general panorama (source: Spim Genova, 2018)

permanent and lasting condition within which institutions must live together and in which they must find the room and the tools with which to manoeuvre.
The static nature of the coexistence is due to the combination of different factors. First, the Italian governance model of urban-port areas is mostly based on the consultation approach. The municipality and the port authority (from the 2016 port system authority) converge only in a certain phase of the planning processes to find agreement and give mutual consent. Generally, this logic does not foresee a shared strategy and mainly pushes the authorities to proceed independently.

However, currently, the municipality is highlighting the importance of carrying out the operative approach of the urban organisms and, with regard to the Waterfront di Levante, is proposing more effective implementation formulas to reduce waiting times and complete programmes within a legislative term. However, this process seems mostly founded on speculation and the privatisation of public areas: tenders for the concession and/or sale of state property will be issued in late 2018, risking to deplete the role of the public bodies involved. 
On the other side, the port is strongly convinced of the importance of proper planning tools able to coordinate different initiatives. The Genoa Port System Authority, in fact, is predominantly committed to building a new Port Plan, paying attention to programme agreements between institutions that should regulate the interests of all, while ensuring the progress of projects.

It is now clear that the temporal misalignment between the two planning processes causes many difficulties, and the consultation along the border does not seem to be the most suitable instrument for managing the complexity of the district. Moreover, the realisation of this long strip project is particularly controversial, since the seafront has been parcelled into pieces belonging to different and conflicting properties.

Going beyond these complications, we have to recognise that the water canal, proposed both for urban and operative uses, is a powerful example of a border project. It will work as an infrastructure, dividing but also joining together the two shores and, for some parts, provide a navigable waterway for both operational and recreational purposes. Furthermore, the canal is a real example of a threshold because it will guarantee continuity and openness, but also a new balance, right on the edge between port and city. Through this operation, the border acquires thickness: the new functions are combined with the rich pre-existing architectural heritage giving life to a linear urban park that links together the Porto Antico district (in the centre of the city) and the eastern waterfront. The construction of the canal and the park, then, serves to rationalise the fair areas and shipyards that, in the current configuration, are pressed against one another, limiting the functionality and potential for future growth.

\section{Conclusions}

\subsection{States of coexistence}

The comparison between the Rotterdam and Genoa border areas highlights the existence of different states of coexistence that are created between city and port.

Coexistence is a disposition that presupposes conflict and sharing, demarcation and overlap at the same time. It allows the project to proceed, keeping opposing components together and welcoming the indefiniteness and the boundless liveliness of the border (Bruttomesso, 2011).

Regarding port-city planning, coexistence implies the overcoming of the ideas of integration and consultation.

Integration between city and port is a principle from the end of the last century that tried to reconstitute an ancient bond through the reconversion of abandoned port areas into new waterfront districts, mainly based on leisure and tourism. However, this cohesion between city and port no longer exists today: the radical evolution of the port-city model, in fact, has increased the divergence between the two entities and has frequently brought about the detachment of the port from its original site. Due to this process, the harmful perception of the port landscape and identity has grown: the preconception that the port is a polluting and negative presence for the city and, consequently, must be kept far from the city's life systems fuels the progressive weakening of its symbolic and cultural value.

In any case, today's port is a different reality that for decades requires autonomy in order to function properly. In this sense, the search for the old integration between urban-port territories is surely a false, inappropriate and even counterproductive goal. A goal that seems to ignore the logisticalcommercial evolution of ports which, instead, requires a new form of equilibrium.

Moreover, consultation is a conditional agreement in which one tries to balance diverse and often opposed interests with often limited results; ultimately, this practice would not seem to provide for a committed and reciprocal exchange of visions. This is not just a matter of terminology: 'coexistence' rather than 'integration' is actually a profound act of awareness that involves an incisive change in perspective, a loyal sharing of commitments, a leap to the next level.

With these standpoints, it is now clear that the idea of coexistence is a totally different strategy that finds its starting point in a neutrality regime: this neutral (but not indifferent) approach is fundamental to building a common ground for discussion and to figuring out a new and collective horizon.

Coexistence is a mutable condition that concretises in diverse states. Its heterogeneity, then, is particularly in tune with the dynamism of the port infrastructure and, in the same way, it is confirmed that the port city is an open system in unstable evolution.

\subsection{Border projects}

Although coexistence is not just a conceptual and theoretical position, it turns out to be the necessary prerequisite for the development of border projects, namely projects able to interpret characteristics of the liminal condition generated by the border with the use of specific attributes.

To give some examples, these solutions are based on the development of hybrid devices with multiple fronts or, alternatively, on the design of a 'third element' (a street, a work of 
architecture, a green space, a water canal) that literally stands in the middle to act as a connection, an interface and a filter. Border projects accept to live with a dynamic and variable regime and, secondarily, try to use it as a design ingredient.

Speaking in terms of architecture, there are building types that, more than others, are able to interpret the border condition (Schoonderbeek, 2010). Among these, there are the stations (railway but also maritime) that, by definition, link merging flows and spaces. Stations are travellers' buildings that have very different sides, embodying the origin and orientation in the component of the façade.

Moreover, the architectural heritage of the port has had a very dual character since very ancient times. The flow of goods indeed required an efficient accessibility by sea and, at the same time, a continuity between the quay's edge and the storage/processing buildings (warehouses, granaries or vinery stores, silos etc.). With the introduction of the container and the affirmation of global logistics in the past century the need to have structures adjacent to the coast persists in most cases, despite the fact that delocalisation in inner territory areas and the dematerialisation of trades are actually increasing. However, mostly due to the role and impact of logistics infrastructure on land, port buildings no longer require a very strong operational character, because they are no longer conditioned and directly shaped by logistics and rules of commerce.

Other functions related to the sea, such as shipyards and nautical services or sports, instead, are still linked to the quay's edge location in order to have immediate access to the water. In these cases, potential border projects, such as a yachting club's headquarters or hangars for refit-repair and shipbuilding, could be developed.

Clearly, the development of border projects necessarily has to deal with the topic of land ownership and, consequently, to manage a controversial process of agreements often developed in successive parts and phases.

\subsection{Plans/projects, strategies/actions}

Through the investigation of states of coexistence and border projects, an important final theme emerges.

The role of planning in contexts such as borders shows the lack of regulation and the general lack of clarity on this topic. In particular, we can detect a sort of divergence between the idea of 'plan' and 'project' and between 'strategies' and 'actions' as well.

'Plan' and 'project/s' are important tools that often seem to be disconnected. 'Projects' are used by the authorities in order to overtake the difficulties and the slow pace of ordinary planning. However, in many cases, these solutions are too visionary or too laborious to approve because they are basically in conflict with planning guidelines. Otherwise, 'plans' take a long time and a great deal of effort to be drafted, becoming obsolete even before being approved.

In this perspective, the recognition of states of coexistence could be a useful practice in other border contexts as well in order to elaborate potential applications and border projects capable of grasping the intermediate and hybrid dimension determined by the urban-port mix.

\section{Acknowledgements}

The authors thank Dr. Simonetta Cenci (deputy mayor, Office for Urban Development and Urban Planning), Dr. Paola Giampietri and Dr. Angela Imbesi (representatives of the Planning and Development Department of the Port System Authority of the Western Liguria) and Dr. Martin Aarts (senior advisor on Urban Planning, former head of Urban Planning in the Rotterdam Municipality), who contributed actively to the development of this research through dialogues and interviews.

\section{REFERENCES}

Bauman Z (2000) Modernità Liquida. Laterza Editore, Rome, Italy (in Italian).

Brambilla C, Laine J and Bocchi G (2015) Borderscaping: Imaginations and Practices of Border Making. Routledge, Abingdon-on-Thames, UK.

Bruttomesso R (2011) Port and city: from integration to coexistence. In The Port City of the XXIst Century. New Challenges in the Relationship between Port and City (Alemany $\mathrm{J}$ and Bruttomesso R (eds)). RETE - Association for the collaboration between ports and cities, Venice, Italy.

BU (Bouw en Uitvoering) (2019) See https://bouwenuitvoering.nl (accessed 13/09/2019).

Castells M (1996a) Lo spazio dei flussi. In La Nascita Della Società in Rete. UBE Paperback, Milan, Italy, pp. 435-491 (in Italian).

Castells M (1996b) Prologo: la rete e l'Io. In La Nascita Della Società in Rete. UBE Paperback, Milan, Italy, pp. 1-26 (in Italian).

Crotti S (2000) Figure Architettoniche: Soglia. Edizioni Unicopli, Milan, Italy (in Italian).

Daamen T and Vries I (2012) Governing the European port-city interface: institutional impacts on spatial projects between city and port. Journal of Transport Geography 27: 4-13.

Ferrara P (2011) Limes. Il confine nell'era postglobale. In: Sophia III (2011-2), pp. 183-194.

Genoa Municipality official websites (2018). See http:/genovameravigliosa.com/en/fronteamare and http://comune. genova.it/content/il-blueprint-10-punti (accessed 04/04/2018).

Genova Meravigliosa (2018) See http://genovameravigliosa. com/en/fronteamare (accessed 16/05/2018).

Hall P (2016) How can joint urban and port planning facilitate the next economy - flexible frameworks of port and city? Presentation at AIVP World Conference, Rotterdam, the Netherlands. 
See http://sfu.ca/ pvhall/pdfs/AIVP_2016_PVHall_distribution.pdf (accessed 23/04/2018).

Harbers A (2005) Borderscapes, the influence of national borders on spatial planning. In Euroscapes - Forum 2003 (Broesi R,

Jannink P, Veldhuis W and Nio I (eds)). MUST Publishers and AetA, Amsterdam, the Netherlands, pp. 143-166.

M4H official web site (2018) See http://m4hrotterdam.nl (accessed 04/04/2018).

MIT (Ministero Italiano delle Infrastrutture e dei Trasporti) (2016) Piano Strategico Della Portualità E Della Logistica. MIT, Rome, Italy (D.lgs. 21/01/2016) (in Italian).

Paasi A (1996) A border theory: an unattainable dream or a realistic aim for border scholars? In The Ashgate Research Companion to Border Studies (Wastl-Walter D (ed.)). Ashgate, London, UK, pp. 1-40.

Port of Rotterdam (2019) See http://portofrotterdam.com (accessed 16/09/2019)

RDM Campus official site (2018) See http://rdmrotterdam.nl (accessed 22/04/2018).

Rumford C (2006) Theorizing borders. European Journal of Social Theory 9(9): 155-169.
Schoonderbeek M (2010) Border Conditions. Architectura \& Natura, Amsterdam, the Netherlands.

Schoonderbeek M (2013) The border as threshold space of simultaneities. Archimaera 5(5): 151-165.

Sennett R (2016) The Public Realm. Essays, Quant, USA. See http://richardsennett.com/site/senn/templates/general2.aspx? pageid $=16 \& \mathrm{cc}=\mathrm{gb}($ accessed 10/04/2018).

Spim Genova (2018) See http://spimgenova.it (accessed 12/05/2018).

Van der Lugt L, de Langen P and Hagdorn L (2013) Beyond the landlord: typologies of port authorities' strategies. Paper Presented at International Association of Maritime Economists (IAME) Conference, Marseille, France.

Waldheim C (2016) Four: post-Fordist economies and logistics landscape. In Landscape as Urbanism. A General Theory. Princeton University Press, Princeton, NJ, USA, pp. 69-85.

Waldheim C and Berger A (2008) Logistic landscape. Landscape Journal 27(2): 219-246.

Zanini P (2000) Significati del Confine. I Limiti Naturali, Storici, Mentali. Bruno Mondadori Editore, Milan, Italy (in Italian).

\section{How can you contribute?}

To discuss this paper, please email up to 500 words to the editor at journals@ice.org.uk. Your contribution will be forwarded to the author(s) for a reply and, if considered appropriate by the editorial board, it will be published as discussion in a future issue of the journal.

Proceedings journals rely entirely on contributions from the civil engineering profession (and allied disciplines). Information about how to submit your paper online is available at www.icevirtuallibrary.com/page/authors, where you will also find detailed author guidelines. 